\title{
Effects of magnesium sulfate and dioctyl sodium sulfosuccinate on fecal hydration, output and systemic hydration in healthy horses
}

[Efeitos do sulfato de magnésio e do dioctil-sulfossuccinato de sódio na hidratação e eliminação fecal e sobre a hidratação sistêmica de cavalos saudáveis]

\author{
J.M. Alonso, C.S. Esper, G.S. Rosa, F.P. Schmitt, F.L. Araújo, G.B. Melo Neto, \\ J.C.F. Pantoja, M.J. Watanabe, A.L.G. Alves, C.A. Rodrigues, C.A. Hussni*
}

Faculdade de Medicina Veterinária e Zootecnia - Universidade Estadual Paulista - Botucatu, SP

\begin{abstract}
Magnesium sulphate (MS) and dioctyl sodium sulphosuccinate (DSS) are laxative drugs frequently used for the treatment of impactions. The aim of this study was to compare the effects of MS and DSS in fecal hydration, output and systemic hydration in healthy horses. Five healthy horses received 3 treatments with a 21-day interval. Treatment 1 was performed with administration of 4 liters of warm water; treatment 2: administration of 4 liters of warm water associated with $1 \mathrm{~g} / \mathrm{kg}$ of MS; and treatment 3: administration of 4 liters of warm water associated with $20 \mathrm{mg} / \mathrm{kg}$ DSS. General and specific physical examination of the digestive system were performed, alongside with packed cell volume and total plasma protein measurement, abdominal ultrasonography and quantification of the amount and hydration of feces, before and 6, 12, 24, 36 and 48 hours after the treatments. No adverse effects were observed. The administration of laxatives promoted greater fecal output and hydration without resulting in systemic dehydration, yet no differences were observed between treatments. The absence of adverse effects of DSS demonstrates the safety of its use as a laxative drug at a dose of $20 \mathrm{mg} / \mathrm{kg}$. Studies comparing the effects of the laxative drugs in horses with large colon impaction are needed.
\end{abstract}

Keywords: laxatives, dehydration, colon impaction

\section{RESUMO}

O sulfato de magnésio (SM) e o dioctil-sulfossuccinato de sódio (DSS) são drogas laxativas frequentemente utilizadas no tratamento da compactação. O objetivo deste estudo foi comparar os efeitos do SM e do DSS na hidratação e eliminação fecal, e na hidratação sistêmica de cavalos saudáveis. Cinco cavalos receberam três tratamentos, com intervalo de 21 dias. O tratamento 1 consistiu na administração de quatro litros de água morna; o tratamento 2: administração de quatro litros de água morna associada a $1 \mathrm{~g} / \mathrm{kg}$ de SM; e o tratamento 3: administração de quatro litros de água morna associada a 20mg/kg de DSS. Foram realizados exames físicos gerais e específicos do trato digestivo, hematócrito e proteína plasmática total, ultrassonografia abdominal e mensuração da quantidade e hidratação das fezes antes e após seis, 12, 24, 36 e 48 horas dos tratamentos. Não foram observados efeitos adversos. A administração de ambos os laxantes promoveu maior produção fecal e hidratação, sem resultar em desidratação sistêmica, entretanto não houve diferença entre os tratamentos. A ausência de efeitos adversos do DSS demonstra a segurança de seu uso como medicamento laxante na dose de $20 \mathrm{mg} / \mathrm{kg}$. São necessários estudos que comparem o efeito dos laxantes em equinos portadores de compactação de cólon.

Palavras-chave: compactação de cólon, hidratação, laxantes

Recebido em 27 de novembro de 2019

Aceito em 6 de março de 2020

*Autor para correspondência (corresponding author)

E-mail: cahussni@fmvz.unesp.br 


\section{INTRODUCTION}

Primary colon impaction is one of the most frequent causes of colic in horses. The treatment of this condition is preferably conservative aiming to control the abdominal pain and dissolve the impacted ingesta using laxatives associated with fluid and electrolyte replacement (Dabareiner and White, 1995; Hacket, 2013). Moderate gastric distension in horses, as in other species, triggers immediate colon motility, known as the gastrocolic reflex. Colon impaction can be treated by administering liquids through a nasogastric tube in order to stimulate colon motility through the gastrocolic reflex, hence contributing to the resolution of the impaction (Freeman et al., 1992; Lopes et al., 2002).

Magnesium sulfate (MS) is the most used laxative in the treatment of impactions. Its osmotic action results in hydration of the impacted mass in the intestinal lumen (Lopes et al., 2002). Dioctyl sodium sulfosuccinate (DSS), another drug used for treatment of impactions, possesses surfactant laxative action. Due to its anionic surfactant feature, DSS is able to penetrate the impacted ingesta and disperse its contents, humidifying and softening the impaction (Southwood et al., 1999). The high occurrence of adverse effects after DSS use at high doses (Moffat et al., 1975; Freeman et al., 1992) has resulted in mystification and reduction of its use in the treatment of impactions. The aim of this study was to compare MS and DSS laxative effects on fecal hydration, output and systemic hydration in healthy horses.

\section{MATERIAL AND METHODS}

This study was conducted in compliance with the Ethics Principles in Animal Experimentation and it was approved by the Ethics Committee on Animal Experimentation (CEUA) (Protocol \# $0086 / 2017$ ). Five horses with mean age of $7.6 \pm 4.4$ years and mean weight of $318 \pm 37 \mathrm{~kg}$ were used for this study. In order confirm the health status, the animals were subjected to previous general and specific physical examination of the digestive system, hemogram, coproparasitological test and abdominal ultrasonography. The animals were housed in individual stalls and fed with coast cross grass hay and water ad libitum.

All horses were subjected to three treatments, respecting a 21day interval between each administration. In treatment 1 (control), 4 liters of warm water $\left(38^{\circ} \mathrm{C}\right)$ were administered; in treatment 2.4 liters of warm water associated with $1 \mathrm{~g} / \mathrm{kg}$ bodyweight of MS were administered; and in treatment 3, 4 liters of warm water associated with $20 \mathrm{mg} / \mathrm{kg}$ bodyweight of DSS were administered. All solutions were administered through nasogastric intubation.

In order to minimize the environmental effects, the solutions were administered in a cross over similar scheme, where in the first administration: 2 horses received water, 2 SM and 1 DSS; after 21 days: 2 received water, 1 SM and 2 DSS; and after 21 days: 1 received water, 2 SM and 2 DSS. The animals were fasted for 12 hours before each phase. No water restriction was applied either before or after the treatments. All the animals received coast cross hay ad libitum 4 hours after the administration, until the end of the study.

The animals were subjected to a general and specific physical examination of the digestive system, abdominal ultrasonography, and measurement of the packed cell volume (PCV) and total plasma protein before and 6, 12, 24, 36 and 48 hours after each administration. At each time point 200 grams of feces were collected to measure humidity. Total fecal output was determined through feces collection and weighing every 6 hours during the 48 hours following each treatment.

The general physical examination included the heart and respiratory rates, mucous membrane color, capillary refill time and rectal temperature. For specific examination of the gastrointestinal tract the abdominal cavity was divided in four quadrants (right and left ventral and dorsal). After auscultating each quadrant for 3 minutes, intestinal motility was graded based on a score system where 0- absence of motility; 1hypomotility; 2 - normal motility and 3 hypermotility. All examinations were carried out by the same evaluator to avoid evaluation bias due to the subjectivity of this parameter.

Blood samples for PCV and total plasma protein evaluation were collected in ethylenediaminetetraacetic acid (EDTA) tubes through jugular venipuncture using a sterile vacuum system. The PCV was determined by the manual method, using a microhematocrit centrifuge. The capillary tube was centrifuged at 
10.000rpm for 5 minutes. Total plasma protein was determined using a refractometer.

Abdominal ultrasonography was focused on intestinal contents and motility. The right dorsal colon (RDC) was evaluated to characterize intestinal content using a grading score system, where 0-dense; 1-moderately liquid and 2-liquid. The small intestine was evaluated for motility aiming to minimize the effect of the evaluator and subjectivity of abdominal auscultation. Motility was evaluated based on the number of complete intestinal movements per minute in the duodenum region.

The determination of the hydration of feces was performed by gravimetry, a laboratory technique used to determine the mass or concentration of a substance by measuring changes in mass (Cecchi, 2003). For that, aliquots of $200 \mathrm{~g}$ of feces were weighed before and after dehydration in an oven at $150^{\circ} \mathrm{C}$ for 24 hours. The water content of the feces was obtained through the weight difference between both measurements.

The data were tested for normality and submitted to non-parametric analysis. Wilcoxon rank sum test was used, and significant results were considered when $\mathrm{P} \leq 0.05$. The analyses were performed with PROC NPAR1WAY (SAS Institute, Cary, NC, USA) at a significance level of 0.05 .

\section{RESULTS AND DISCUSSION}

No significant differences were observed in heart and respiratory rates, mucosal color, capillary refill time and rectal temperature between treatments or time points. All parameters remained within the normal range for the species (Southwood et al., 1999; Feitosa, 2000). There was no significant difference in intestinal auscultation scores between the time points or treatments. Intestinal spasms and hypermotility occurred predominantly 6 hours after administration and lasted up to 24 hours in MS and DSS treatments, even though no signs of associated abdominal pain were observed.

The packed cell volume increased significantly $(\mathrm{P}=0.0449)$ in DSS treatment compared to MS 6 hours after administration (Table 1). This difference was not accompanied by increase in total plasma protein (Table 1). Although the TPP was relatively higher in DSS group at this time point, it remained within the physiologic reference values for the species (Feitosa, 2000).

Table 1. Median [first (Q1) - third quartile (Q3)] of the PCV and total plasma protein of the horses that received Water, Magnesium sulphate (MS) and Dioctyl sodium sulphosuccinate (DSS)

\begin{tabular}{lcccccc}
\hline \multirow{2}{*}{$\begin{array}{c}\text { Time } \\
\text { (h) }\end{array}$} & \multicolumn{2}{c}{ Packed Cell Volume $^{1}(\%)$} & \multicolumn{2}{c}{ Total plasma protein $^{2}(\mathrm{~g} / \mathrm{dL})$} \\
\cline { 2 - 7 } & Water & MS & DSS & Water & MS & DSS \\
\hline 0 & $35[29-37]^{\mathrm{a}}$ & $32[28-35]^{\mathrm{a}}$ & $29[26-34]^{\mathrm{a}}$ & $6.4[6.2-7.0]^{\mathrm{a}}$ & $6.4[6.0-7.6]^{\mathrm{a}}$ & $6.4[6.0-7.0]^{\mathrm{a}}$ \\
6 & $33[32-35]^{\mathrm{ab}}$ & $32[30-32]^{\mathrm{a}}$ & $32[29-35]^{\mathrm{b}}$ & $6.0[5.8-7.2]^{\mathrm{a}}$ & $6.2[6.0-7.4]^{\mathrm{a}}$ & $6.6[6.2-7.0]^{\mathrm{a}}$ \\
12 & $35[30-37]^{\mathrm{a}}$ & $35[31-37]^{\mathrm{a}}$ & $31[29-34]^{\mathrm{a}}$ & $6.8[5.6-7.0]^{\mathrm{a}}$ & $6.2[6.0-7.6]^{\mathrm{a}}$ & $6.4[6.0-7.4]^{\mathrm{a}}$ \\
24 & $34[30-37]^{\mathrm{a}}$ & $34[29-35]^{\mathrm{a}}$ & $29[26-35]^{\mathrm{a}}$ & $6.2[5.6-6.6]^{\mathrm{a}}$ & $6.4[6.0-7.4]^{\mathrm{a}}$ & $6.8[6.0-7.2]^{\mathrm{a}}$ \\
36 & $34[31-35]^{\mathrm{a}}$ & $33[29-34]^{\mathrm{a}}$ & $29[28-33]^{\mathrm{a}}$ & $6.0[5.4-7.0]^{\mathrm{a}}$ & $6.1[6.0-6.6]^{\mathrm{a}}$ & $6.2[6.0-7.4]^{\mathrm{a}}$ \\
48 & $34[33-36]^{\mathrm{a}}$ & $32[28-33]^{\mathrm{a}}$ & $29[26-30]^{\mathrm{a}}$ & $6.2[3.4-7.0]^{\mathrm{a}}$ & $6.2[6.0-7.2]^{\mathrm{a}}$ & {$[6.0-7.0]^{\mathrm{a}}$} \\
\hline
\end{tabular}

1,2 - Different letters within the same row indicate significant difference between medians $(\mathrm{P}<0.05)$.

The measurement of PCV and total plasma protein is an objective method to determine the hydration status (Pritchard et al., 2006). The significant difference found in PCV 6 hours after administration suggests a greater mobilization and maintenance of water within the intestinal lumen. Even with an increase in PCV, these results do not characterize dehydration, since there was no difference or increase exceeding TPP normality values at the same time. It is important to point out that the animals were not deprived of water intake, aiming to mimic a clinical condition where animals receive laxatives and remain with free access to water and/or receiving enteral or intravenous fluid therapy.

The comparison between treatments and time points of the hydration scores of the right dorsal colon showed a more fluid content at 24 hours in the MS treatment $(\mathrm{P}=0.0302)$. Since there was no significant increase in the fecal humidity of the MS group, this difference was attributed to the different action mechanisms of the laxatives. DSS, in addition to breaking the surface tension, 
aiding the penetration of liquid in the ingesta, also inhibits the absorption of water along the small intestine and colon (Ferreira et al., 2009). Through these mechanisms, the amount of liquid in the segments is maintained along the gastrointestinal tract. Magnesium sulphate, on the other hand, possesses osmotic action and appears to promote water secretion induced by the vagal gastrocolic reflex (Freeman et al., 1992). Even though the absorption of a little amount of magnesium can occur (Avanza et al., 2009), the results of this study suggest that MS administration leads to a heterogeneous amount of liquid in the intestinal lumen. However, since the final fecal humidity was similar between the treatments, the water was subsequently absorbed on transverse and small colon.

Ultrasonographic examination is more sensitive and objective to detect changes in intestinal motility than intestinal auscultation (Reef, 1998; Jones et al., 2003). Auscultation is a subjective method and depends on the performer (Vanderbroek et al., 2018). At ultrasonographic examination, the duodenum motility presented a significant increase in MS and DSS groups when compared to the control group 12 hours after administration $(\mathrm{P}=0.0432)$. However, there was no difference between MS and DSS.

Adverse effects related to the use of DSS, such as dehydration, abdominal pain, spasms and profuse diarrhea were reported in dosages of $50 \mathrm{mg} / \mathrm{kg}$ (Freeman et al., 1992) and 200mg/kg (Moffat et al., 1975). The therapeutic dose of DSS varies between 10 and $50 \mathrm{mg} / \mathrm{kg}$ (Sprayberry and Robinson, 2014). A dose of $20 \mathrm{mg} / \mathrm{kg}$ demonstrated safe results, since no adverse effects such as signs of abdominal pain or diarrhea were observed. Even though spasms occurred in both laxative treatments (MS and DSS), the animals did not show manifestations of colic. Additionally, the safety of this dosage is reinforced by the stability of physical examination and PCV values.

A bigger frequency of fecal outputs was observed in DSS treatment along the 48 hour evaluation. However, no significant differences were achieved (Figure 1). No differences were obtained even between time points.
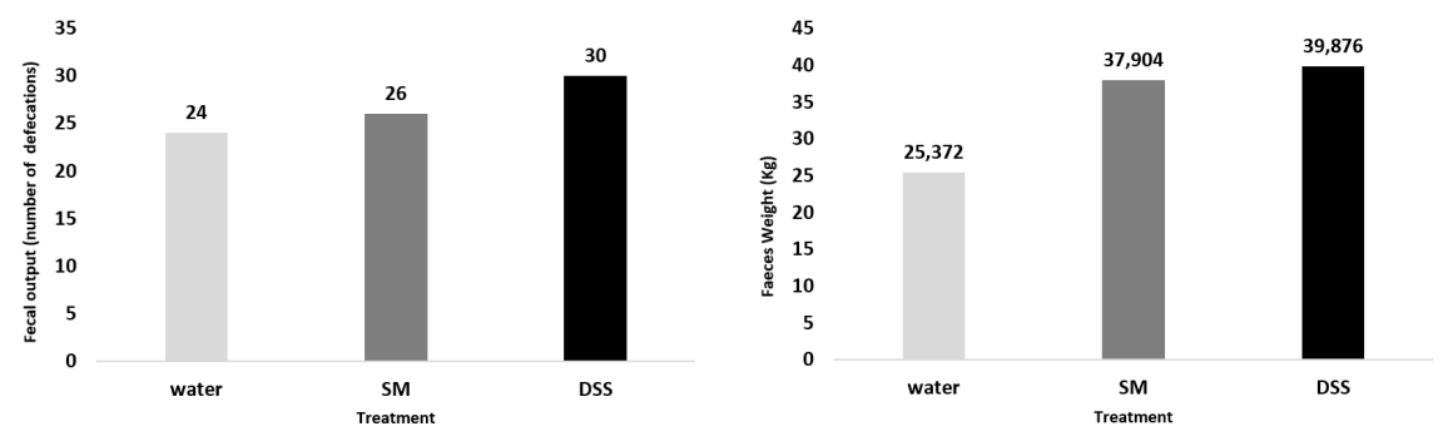

Figure 1. Median of the total number of defecations and total weight of feces eliminated in 48 hours after administration of water, magnesium sulphate (MS) and Dioctyl sodium sulphosuccinate (DSS) in the horses

The median hydration of the feces in control group was 68\% (Q1-Q3: 58-82), significant lower than $77 \%$ in MS group (Q1-Q3: 70-85) and $79 \%$ obtained in DSS treatment (Q1-Q3:74-85) during the $48 \mathrm{~h}$ observation period $(\mathrm{P}=0.0323)$. Higher hydration of the feces was also observed between
6 and 24 hours after administration of the laxatives. However, no significant differences were observed between the treatments at different time points (Figure 2). 


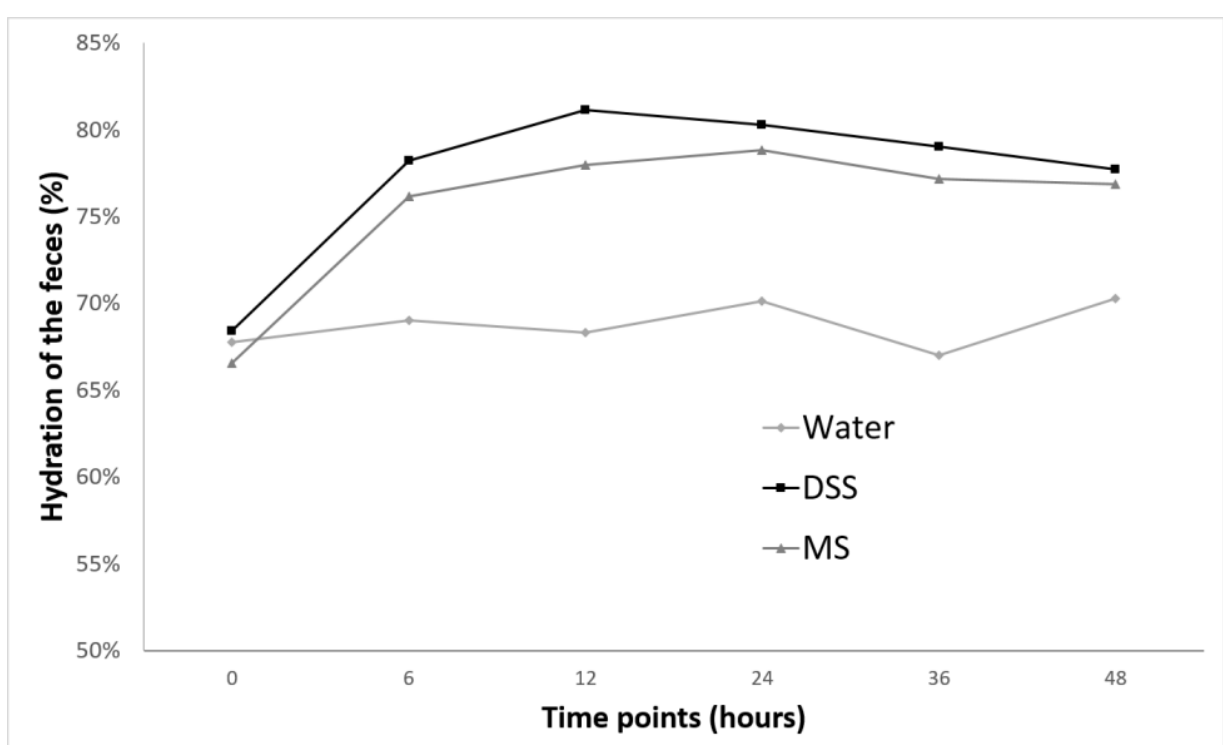

Figure 2. Hydration of the feces throughout the evaluation time points in the horses that received water, magnesium sulphate and (MS) and dioctyl sodium sulphosuccinate (DSS)

\section{CONCLUSION}

The results indicate a similar potential between MS and DSS on fecal mass formation and humidity, without resulting in systemic dehydration. Both drugs were able to increase intestinal motility and RDC content fluidity. Even though some spasms can occur after administration, no adverse effects related to abdominal pain or diarrhea were observed. Additional studies are still necessary to evaluate the molecular events that occur after administration of these drugs. Lastly, the absence of adverse effects after the administration of DSS at a dose of $20 \mathrm{mg} / \mathrm{kg}$ substantiates the safety of its use as a laxative drug.

\section{REFERENCES}

AVANZA, F.B.; RIBEIRO FILHO, D.; LOPES, M.A.F. et al. Hidratação enteral em equinossolução eletrolítica associada ou não à glicose, à maltodextrina e ao sulfato de magnésio: resultados de laboratório. Ciênc. Rural, v.39, p.1116-1123, 2009.

CECCHI, H.M. Fundamentos teóricos e práticos em análise de alimentos. São Paulo: UNICAMP, 2003. 206p.

DABAREINER, R.M.; WHITE, N.A. Large colon impaction: 147 cases (1985-1991). J Am. Vet. Med. Assoc., v.206, p.679-685, 1995.
FEITOSA, F.L. Semiologia veterinária: a arte do diagnóstico. São Paulo: Roca, 2000. 644p.

FERREIRA, C.; PALHARES, M.S.; MELO, U.P.; GHELLER, V.A.; BRAGA, C.E. Cólicas por compactação em equinos: etiopatogenia, diagnóstico e tratamento. Acta Vet. Bras., v.3, p.117-126, 2009.

FREEMAN, D.E.; FERRANTE, P.L.; PALMER, J.E. Comparison of the effects of intragastric infusions of equal volumes of water, dactyl sodium sulfosuccinate, and magnesium sulfate on fecal composition and output in clinically normal horses. Am. J. Vet. Res., v.53, p.1347-1353, 1992.

HACKET, E.S. Practical guide to equine colic: specific causes of colic. New Jersey: John Wiley and Sons, Inc., 2013. p.215-220.

JONES, S.L.; DAVIS J.; ROWLINGSON, K. Ultrasonographic findings in horses with right dorsal colitis: Five cases (2000-2001). J. Am. Med. Assoc., v.222, p.1248-1251, 2003.

LOPES, M.A.; WALKER, B.L.; WHITE, N.A. Treatments to promote colonic hydration: enteral fluid therapy versus intravenous fluid therapy and magnesium sulphate. Equine Vet. J., v.34, p.505509, 2002. 
MOFFAT, R.E.; KRAMER, L.L.; LERNER, D.; JONES, R. Studies on dactyl sodium sulfosuccinate toxicity: clinical, gross and microscopic pathology in the horse and guinea pig. Can. J. Comp. Med., v.39, p.434, 1975.

PRITCHARD, J.C.; BARR, A.R.S.; WHAY, H.R. Validity of a behavioural measure of heat stress and a skin tent test for dehydration in working horses and donkeys. Equine Vet. J., v.38, p.433-438, 2006.

REEF, V.B. Equine diagnostic ultrasound. Philadelphia: WB Saunders Company, 1998. p.547.

SOUTHWOOD, L.L.; SCHOTT, H.C.; WUNN, D.; HOPPER, S.A.; BAYLY, W.M. Effects of dioctyl sodium sulfosuccinate on hematological values in normal horses. J. Equine Vet. Sci., v.19, p.266-270, 1999.
SPRAYBERRY, K.A.; ROBINSON, N.E. Robinson's current therapy in equine medicine. St. Louis: Elsevier, 2014. 285p.

VANDERBROEK, A.R.; REEF, V.B.; AITKEN, M.R.; STEFANOVSKI, D.; SOUTHWOOD, L.L. Assessing gastrointestinal motility in healthy horses comparing auscultation, ultrasonography and an acoustic gastrointestinal surveillance biosensor: a randomised, blinded, controlled crossover proof of principle study. Equine Vet. J., v.51, p.246-251, 2018. 